August Cesarec, mag. oec., univ. mag. admin. sanit.*

\title{
EKONOMSKI UTJECAJ NEPRIHODUJUĆIH KREDITA U ZEMLJAMA SREDNJE I ISTOČNE EUROPE
}

\section{ECONOMIC IMPACT OF THE NON-PERFOFMING LOANS IN CENTRAL AND EASTERN EUROPEAN COUNTRIES}

\begin{abstract}
SAŽETAK: Rad istražuje utjecaj povećanja razine neprihodujućih kredita na kretanje bruto domaćeg proizvoda, nezaposlenost i udio kredita u bruto domaćem proizvodu za11 zemalja Srednje i Istočne Europe između 2008. i 2019. Ekonomski utjecaj neprihodujućih kredita razmatran je korištenjem panel vektorskog autoregresijskog modela te funkcije impulsnog odziva. Rezultati rada dokazuju snažan i dugotrajan negativan utjecaj povećanja neprihodujućih kredita na bruto domaći proizvod i nezaposlenost. Navedeni rezultati važni su s obzirom na značaj bankovnih kredita u zemljama Srednje i Istočne Europe te mogući negativan utjecaj koronakrize na kvalitetu bankovne aktive.
\end{abstract}

KLJUČNE RIJEČI: neprihodujući krediti, banke, makro-financijske veze, funkcija impulsnog odziva

SUMMARY: The paper investigates impact of the non-performing loans increase on the gross domestic product, unemployment and share of bank loans in gross domestic product for the 11 Central and Eastern European Countries between 2008 and 2019. Economic impact of non-performing loans is analysed by applying panel vector autoregressive model and impulse response function. Results of the paper indicate strong and lasting impact of the non-performing loans increase on the gross domestic product and unemployment. The mentioned results are relevant taking into consideration importance of bank's loans in Central and Eastern European countries and possible negative impact of the COVID-19 crisis on the quality of banking assets.

KEYWORDS: non-performing loans, banks, macro-financial linkages, impulse response function

August Cesarec, mag. oec., univ. mag. admin. sanit., asistent, Ekonomski fakultet Sveučilišta u Zagrebu, Trg J. F. Kennedyja 6, 10000 Zagreb, Hrvatska 


\section{UVOD}

Banke su najvažnije financijske institucije europodručja i Europe, a odobreni krediti najvažniji aktivni posao i izvor prihoda banaka (Europska bankovna federacija, 2020; Europska središnja banka, 2020). Osim za banke, krediti banaka važni su i europskim poduzećima i stanovništvu kao najvažniji eksterni izvor financiranja te samim time pad kreditnog obujma ili manja kvaliteta bankovnih kredita mogu imati snažan utjecaj na makroekonomska kretanja (Cappiello et al., 2010; Banka za međunarodna poravnanja, 2018).

Prilikom odobravanja kredita, banke koriste napredne statističke alate i metode kako bi kvalitetno procijenile kreditnu sposobnost svojih komitenata i odobrile kredite koji će se moći vraćati u skladu s ugovorom. Unatoč navedenim preventivnim mjerama koje banke poduzimaju te korištenju instrumenata osiguranja naplate, kod dijela bankovnih kredita javlja se problem neotplate, što uzrokuje djelomičan ili čak i potpuni otpis potraživanja. Opisani krediti banaka klasificiraju se kao neprihodujući krediti (dodatno loši krediti ili djelomično nadoknadivi i potpuno nenadoknadivi krediti banaka, engl. non-performing loans, NPL).

Razina neprihodujućih kredita banaka može imati snažan utjecaj na poslovne rezultate banaka, ali i uzrokovati bankovne krize te imati širi negativan ekonomski utjecaj. U Europskoj uniji, kao posljedica globalne financijske krize 2008. i europske dužničke krize, udio neprihodujućih kredita u svim kreditima krajem 2016. iznosio je relativno visokih 5,1 \% (Vijeće Europske unije, 2017). Zbog toga je, s ciljem smanjenja neprihodujućih kredita i poticanja ekonomske aktivnosti,2017. godine Europska komisija donijela Akcijski plan za borbu protiv neprihodujućih kredita.

Iako je navedeni akcijski plan, poduprt i stabilnim ekonomskim rastom te makroekonomskim prilikama, doprinio sniženju neprihodujućih kredita u Europskoj uniji, posljednja svjetska financijska kriza pokazala je veću ranjivost i osjetljivost europskog gospodarstva na porast neprihodujućih kredita te krizu financijskog sektora. U bližoj budućnosti, kao posljedica ekonomske krize zbog pandemije bolesti COVID-19 i prestanka moratorija na odobrene kredite, EU će se zasigurno ponovno suočiti s povećanjem neprihodujućih kredita i posljedično sporijim ekonomskim oporavkom. Zbog toga je cilj rada istražiti ekonomski utjecaj povećanja razine neprihodujućih kredita u zemljama Srednje i Istočne Europe.

\section{PREGLED LITERATURE}

Znanstvena istraživanja i teorija već duže razdoblje ističu povezanost financijskog sustava i ekonomskih kretanja. Potrebno je naglasiti važnost procikličnosti i međusobnog utjecaja financijskog sustava i ekonomskih kretanja (Bernanke i Gertler, 1989). Naime, u dobrim vremenima snažne bilance poduzeća podupiru veće zahtjeve za investicijama i time dodatno osnažuju ekonomski rast, a u lošim vremenima događa se obratna situacija. Opisana teorija ,financijskog akceleratora“ dodatno je istaknuta otežanim dobivanjem kredita poduzeća s visokim agencijskim troškovima u vremenima recesije, čime se dodatno produbljuje restriktivnija kreditna politika banaka i pad ekonomske aktivnosti (Bernanke et al., 1996). 
Razina neprihodujućih kredita banaka, koja je ovisna o makroekonomskim kretanjima i kvaliteti upravljanja bankom, može imati dugoročno snažan i negativan utjecaj na ekonomska kretanja i poslovne rezultate banaka. Ari et al. (2019) istraživali su trajanje i utjecaj 88 bankovnih kriza od 1990 godine. Autori zaključuju kako je ekonomski utjecaj neprihodujućih kredita značajno snažniji u zemljama gdje je tijekom bankovne krize došlo do većeg povećanja razine neprihodujućih kredita (razina neprihodujućih kredita iznad $7 \%$ odobrenih kredita). U odnosu na zemlje i bankovne krize s nižom razinom neprihodujućih kredita, bankovne krize praćene povišenom razinom neprihodujućih kredita imaju prosječno $1,6 \%$ niži rast BDP-a u prvoj godini nakon krize te ukupno 6,5 \% do kraja šeste godine.

Espinoza i Prasad (2010) analiziraju čimbenike nastanka i ekonomski učinak neprihodujućih kredita za 6 zemalja Perzijskog zaljeva u razdoblju 1995. - 2008. Koristeći metodu panel vektorskog autoregresijskog modela (panel VAR-a), autori dokazuju kako porast neprihodujućih kredita za jednu standardnu devijaciju $(2,1 \%)$ uzrokuje pad odobrenih kredita za 2,2 \% u tri godine te pad bruto domaćeg proizvoda (BDP-a, korigiranog za naftni sektor) za $0,8 \%$ u prvoj godini. Autori zaključuju kako porast NPL-a dovodi do snažne, ali kratke korekcije NPL-a na ekonomska kretanja, što se može pripisati promatranom razdoblju u kojem nisu evidentirane sustavne bankovne krize.

Nkusu (2011) istražuje makroekonomske čimbenike neprihodujućih kredita te međusobni odnos neprihodujućih kredita i makroekonomskih varijabli u 26 naprednih ekonomija između 1998. i 2009. godine putem metode panel VAR-a. Rezultati dokazuju kako porast razine neprihodujućih kredita za jednu standardnu devijaciju $(2,4 \%)$ uzrokuje pad BDP-a za $0,6 \%$ u prvoj godini te kumulativno $1,1 \%$ u četvrtoj godini. Porast razine NPL-a također dovodi do pada udjela odobrenih kredita privatnom sektoru u BDP-u te pada cijena nekretnina.

Odnos kvalitete bankovne aktive i ekonomskih kretanja, kao i makroekonomske čimbenike nastanka neprihodujućih kredita, u 26 zemalja svrstanih u kategoriju tržišta u nastajanju istražuju De Bock i Demyanets (2012). Fokus autora je na razdoblju 1996. - 2010. te za utvrđivanje utjecaja NPL-a na ekonomska kretanja autori koriste tehniku panel VAR-a. Istraživanje zaključuje kako pogoršanje kvalitete bankovne aktive uzrokuje pad ekonomske aktivnosti i deprecijaciju nominalnog deviznog tečaja. Dekompozicija varijance dodatno pokazuje kako se oko $9 \%$ varijacije realnog ekonomskog rasta u narednim razdobljima može pripisati porastu NPL-a.

Čimbenike nastanka NPL-a i utjecaj pogoršanja kvalitete odobrenih kredita na makroekonomska kretanja u zemljama Srednje, Istočne i Jugoistočne Europe istražuje Klein (2013). Autor u radu obuhvaća razdoblje 1998. - 2011. putem tehnike panel VAR-a te zaključuje kako porast razine NPL-a od $1 \%$ ima negativan i statistički značajan učinak na pad odobrenih kredita (-1,7\% u tri godine), stope inflacije (-0,6 \% u tri godine), BDP-a (-1 \% u dvije godine) te porast nezaposlenosti ( $0,5 \%$ u tri godine). Porast razine NPL-a također objašnjava i značajan postotak varijacije promatranih varijabli u narednim razdobljima (oko $10 \%)$.

Kjosevski i Petkovski (2017) istraživali su čimbenike i makroekonomski utjecaj neprihodujućih kredita u Baltičkim zemljama (Estonija, Latvija i Litva) između 2005. i 2014. Putem metode panel VAR-a, rezultati pokazuju kako porast NPL-a dovodi do pada odobrenih kredita privatnom sektoru (kao postotak BDP-a), inflacije i BDP-a te porasta nezaposlenosti. Ekonomski utjecaj NPL-a u Češkoj u razdoblju 2005. - 2016. metodom vektorskog 
autoregresijskog modela (VAR) analiziraju Petkovski, Kjosevski i Jovanovski (2018). Dokazuje se kako porast razine NPL-a uzrokuje pad razine BDP-a i inflacije te porast nezaposlenosti i odobrenih kredita privatnom sektoru (kao postotak BDP-a).

Pretragom literature može se zaključiti kako porast razine neprihodujućih kredita u svim promatranim razdobljima i zemljama (regijama) ima negativan utjecaj na izabrane makroekonomske varijable, primarno rast bruto domaćeg proizvoda, nezaposlenost, inflaciju i odobrene kredite privatnom sektoru kao najčešće korištene varijable u ekonometrijskim modelima. Izuzev studije Petkovski, Kjosevski i Jovanovski koja se orijentira na jednu državu, sve ostale studije orijentiraju se na više država te za dokazivanje međusobnog utjecaja NPL-a i makroekonomskih varijabli koriste tehniku panel VAR-a.

\section{PODACI I METODOLOGIJA}

\subsection{Izvori podataka}

Podaci za rad prikupljeni su iz sekundarnih izvora podataka za razdoblje 2008. - 2019. U obzir su uzeti godišnji podaci za 11 država Europske unije nastalih raspadom bivših socijalističkih država koje se svrstavaju u zemlje Srednje i Istočne Europe: Bugarska, Češka, Estonija, Hrvatska, Latvija, Litva, Mađarska, Poljska, Rumunjska, Slovačka i Slovenija. Ekonometrijski model uključuje četiri varijable: razina neprihodujućih kredita banaka u ukupnim kreditima banaka (NPL), postotak promjene bruto domaćeg proizvoda na godišnjoj razini (BDP), postotak odobrenih kredita banaka privatnom sektoru kao udio u BDP-u (KRED) i postotak nezaposlenih osoba u ukupnoj radnoj snazi (NEZ). Podaci o vrijednostima varijabli prikupljeni su iz baza podataka Međunarodnog monetarnog fonda (varijabla NPL-a, baza „Financial Soundness Indicators”; varijabla NEZ, baza „World Economic Outlook“) i Svjetske banke (varijable BDP i KRED, baza „World Development Indicators"). Za obradu podataka korišten je softverski program Stata.

S obzirom na to da se u radu promatra ekonomski utjecaj neprihodujućih kredita na izabrane makroekonomske varijable, bitno je istaknuti kako ne postoji jedinstvena definicija neprihodujućih kredita. Baza „Financial Soundness Indicators“ Međunarodnog monetarnog fonda, iz koje su preuzeti podaci o neprihodujućim kreditima, daje sljedeću definiciju neprihodujućih kredita: a) ,plaćanje glavnice ili kamata kasni 90 ili više dana ili b) plaćanje kamata (u ukupnom iznosu za 90 ili više dana) je kapitalizirano, refinancirano ili odgođeno sporazumom" (Međunarodni monetarni fond, 2019). Dodatno, kredite je potrebno klasificirati kao neprihodujuće i ako plaćanje glavnice i kamata ne kasni 90 ili više dana, ali postoje dokazi da se krediti klasificiraju kao neprihodujući (primjerice bankrot ili stečaj).

Nakon posljednje financijske krize, Baselski odbor za nadzor banaka 2016. objavio je određene smjernice s ciljem harmonizacije definicije neprihodujućih kredita banaka (primjerice kriterij priznavanja od 90 dana; kolateral ne utječe izravno na klasifikaciju kredita, ali može utjecati na vjerojatnost otplate). Na području Europske unije, definicija neprihodujućih kredita u bonitetnom okviru uskladila se s onom prilikom nadzora bankovnog sektora i izvješćivanja (Baselski odbor za nadzor banaka, 2016; Europska komisija, 2019). Unatoč sve većoj harmonizaciji definicije, s obzirom na to da se u radu promatra duže vremensko 
razdoblje 2008. - 2019., razlike u definicijama neprihodujućih kredita mogle su se temeljiti na različitom broju dana kašnjenja, klasificira li se cijeli kredit kao neprihodujući ili samo kašnjenje te pitanju klasifikacije ostalih odobrenih kredita istog dužnika (Monokroussosi Gortsos, 2017).

\subsection{Panel vektorski autoregresijski model}

Vektorski autoregresijski (VAR) modeli omogućuju testiranje uzročnosti između pojedinih varijabli, ali i nude nadogradnju ekonometrijskih modela u vidu analize dinamike skupine pojava (Bahovec i Erjavec, 2009). Uz vremenske VAR modele, koji obuhvaćaju samo jednu prostornu jedinicu, razvijeni su i panel vektorski autoregresijski (panel VAR) modeli koji omogućuju više prostornih komponenti, odnosno u kontekstu ovog rada više država. Najvećim prednostima panel VAR modela ističu se: uključivanje statičkih i dinamičkih međuovisnosti, razmatranje odnosa između jedinica bez restrikcija, uključivanje vremenskih oscilacija među koeficijentima i varijacijama šokova te razmatranje dinamičke heterogenosti među prostornim komponentama (Canova i Ciccarelli, 2013).

Panel VAR modeli za $\mathrm{N}$ jedinica promatranja mogu se zapisati sljedećom formulom (Schnücker, 2016):

$$
\mathbf{Y}_{t}=\mathbf{A}_{1} \mathbf{Y}_{t-1}+\mathbf{A}_{2} \mathbf{Y}_{t-2}+\ldots .+\mathbf{A}_{p} \mathbf{Y}_{t-p}+\mathbf{U}_{t} ; \mathrm{i}=1, \ldots ., \mathrm{N}, \mathrm{t}=1, \ldots, \mathrm{T}_{i}
$$

pri čemu je $\mathbf{Y}_{t}$ vektor zavisnih varijabli, $\mathbf{A}_{l}, \mathbf{A}_{2}, \ldots . \mathbf{A}_{p}$ vektor parametara koje treba procijeniti i $\mathbf{U}_{t}$ vektor slučajnih smetnji.

U panel VAR modelima, uvid u dinamičke odnose između varijabli pružaju metode inovacijske analize: funkcija impulsnog odziva (engl. impulse response function, IRF) i dekompozicija varijance (engl. decomposition of variance, DVC) (Bahovec i Erjavec, 2009). Metoda impulsnog odziva pri tome mjeri odgovor (reakciju) svake varijable na jedinični „šok“ (inovacije $e_{\text {it }}$-šok i-te varijable u trenutku t) druge varijable, a dekompozicija varijance utvrđuje koliki dio varijabilnosti pojedine varijable je posljedica šoka u samoj varijabli, a koliki dio posljedica šokova u ostalim varijablama modela. Prilikom izračuna funkcije impulsnog odziva i dekompozicije varijance važan je poredak varijabli modela.

Naime, impulsni odziv odnosi se na analizu jediničnog „šoka“ jedne VAR jednadžbe (jedne varijable) te navedeno podrazumijeva da su greške relacije ostalih varijabli konstantne (Brooks, 2014). Budući da se ipak može očekivati određena korelacija grešaka relacije između različitih varijabli, uobičajeno se koristi ortogonalizacija funkcija impulsnog odziva. Korištenjem ortogonalizacije sva korelacija grešaka relacije pripisuje se varijabli koja je prva poredana u modelu (Love i Zicchino, 2006; Brooks, 2014). Najčešće korištena ortogonalizacija je Choleskyjeva dekompozicija koja podrazumijeva kako su varijable koje su prve poredane u modelu egzogene (šokovi tih varijabli utječu na ostale varijable trenutno), dok se varijable prema kraju smatraju sve više endogenima (šokovi tih varijabli utječu na ranije poredane varijable s vremenskim odmakom) (Klein, 2013; Abrigo i Love, 2016). U ovom radu, prema metodologiji studije Klein (2013), pretpostavlja se da rast BDP-a i nezaposlenost utječu na razinu neprihodujućih kredita s vremenskim odmakom, dok razina neprihodujućih kredita ima trenutan utjecaj na ekonomske aktivnosti putem kredita. Navedeno također uzima u obzir i činjenicu kako se krediti, temeljem bankovne regulative 
i računovodstvenih standarda, ne klasificiraju kao neprihodujući odmah po kašnjenju, nego su to najčešće krediti s kašnjenjima preko 90 dana, što dodatno podupire tezu da makroekonomske varijable utječu na neprihodujuće kredite s određenim vremenskim odmakom. Zbog navedenog, varijabla NPL se koristi prva u poretku, a nakon nje slijede varijable odobrenih kredita (KREZ), nezaposlenosti (NEZ) i promjene bruto domaćeg proizvoda (BDP).

Važno je ipak naglasiti da znanstvena istraživanja nisu usuglašena oko međupovezanosti između financijskog sektora i gospodarskog rasta. S jedne strane, dio znanstvenika ističe kako rast financijskog sustava doprinosi ekonomskom rastu, dok druga skupina autora naglašava kako se financijski sustavi razvijaju kao posljedica ekonomskog rasta (Schumpeter, 1911; Singh, 1997; Levine, 1997; Lucas, 1998). Istraživanja ipak ukazuju da financijski sustav i razina njegove razvijenosti doprinose ekonomskom rastu, a u ekonomski razvijenijim zemljama prisutan je dublji financijski sustav s većim brojem financijskih institucija i instrumenata koji osigurava dostupnost financijskih sredstava za investicije i inovacije i prilikom snažnih negativnih šokova u ekonomiji (Demirgüc-Kunt i Levine, 1999; Međunarodni monetarni fond, 2012).

Povećanje razine neprihodujućih kredita ima i indirektan utjecaj na makroekonomske pokazatelje kroz djelovanje na bilance te račun dobiti i gubitka poduzeća. Naime, u većini zemalja Europe i u ovoj studiji promatranih zemalja prisutni su kreditni registri putem kojih banke razmjenjuju informacije o svojim dužnicima i njihovim kreditnim obvezama. U malo manje od $50 \%$ država koje imaju kreditne registre, kreditori (banke) su i zakonski obvezni savjetovati se s registrima prije odobravanja kredita (Association of Consumer Credit Information Suppliers, 2021). Zbog toga su poduzeća s djelomično ili potpuno neprihodujućim kreditima u otežanoj mogućnosti za refinanciranje svojih dugova kod drugih banak,a što je osobito važno s obzirom na bankocentričnost europskog financijskog sustava. Navedeno također pridonosi manjoj razini investicija i novih poslovnih projekta te time ima negativan utjecaj na makroekonomska kretanja.

\subsection{Analiza bankovnih sektora promatranih zemalja}

Zemlje Srednje i Istočne Europe su se tijekom 1990-ih godina suočile sa snažnim ekonomskim i društvenim izazovima zbog prelaska s planskih na tržišna gospodarstva. U financijskom sektoru važno je za taj period istaknuti nedostatak snažnih financijskih posrednika (primjerice banaka, osiguravatelja, mirovinskih fondova) te nedostatak financijske infrastrukture, uključujući i regulatorne institucije. Ipak, već početkom 2000. godine većina zemalja imala je izgrađen snažan financijski, a osobito bankarski sustav. Unatoč mnogobrojnim razlozima, mogu se istaknuti dva važna čimbenika: rani ulazak stranih banaka i izgradnja kvalitetnih institucija (Haselmann et al., 2016). Ulazak stranih banaka na tranzicijska tržišta tijekom 1990-ih godina omogućio je veću učinkovitost bankovnih sustava te korištenje naprednih tehnologija, tehnika upravljanja kreditnim rizikom i upravljanja ljudskim resursima, što je sve doprinijelo ubrzanom razvoju bankovnog sektora i posredništva (Bonin, 2005; Iwanicz-Drozdowska et al., 2018). Brza tranzicija financijskog sektora na tržišna načela dodatno je poduprta izgradnjom institucionalnog okvira u vidu supervizijskih institucija financijskog sektora te donošenju zakonskih okvira za banke i monetarne financijske institucije (Haselmann et al., 2016). 
Posljednjih nekoliko godina, bankarski sektor u promatranim zemljama, kao i na području Europe, karakterizira konsolidacija bankovnog sektora i rast kreditne aktivnosti, pri čemu su krediti u 2019. prosječno činili $73 \%$ aktive bankovnog sektora u promatranih 11 zemalja (Europska bankovna federacija, 2020). Važnost kredita za poslovne rezultate banaka vidljiva je i iz udjela neto kamatnih prihoda u ukupnim prihodima koji se u cijelom razdoblju kreću između 54 i $66 \%$, uz trend pada do 2013. te rasta udjela od navedene godine. Financijska stabilnost bankovnih sektora na visokoj je razini uz pozitivne trendove. Udio regulatornog kapitala u rizikom ponderiranoj aktivi tako je bio stabilan i u kriznim vremenima te je znatno iznad minimalno propisanih regulatornih vrijednosti, dok je udio nepokrivenih neprihodujućih kredita rastao do 2010. godine te od onda doživio snažan pad na vrijednost omjera $10 \%$ u 2019. (grafikon 1). Profitabilnost bankovnog sektora bila je snažno pogođena financijskom krizom uz primjetan trend snažnog rasta profitabilnosti između 2013. i 2016. Stopa povrata na aktivu od 2016. godine kreće se oko 1,3 \% te je na razini pretkriznih vremena.

Grafikon 1. Izabrani pokazatelji poslovanja banaka (prosječna vrijednost u svim zemljama)

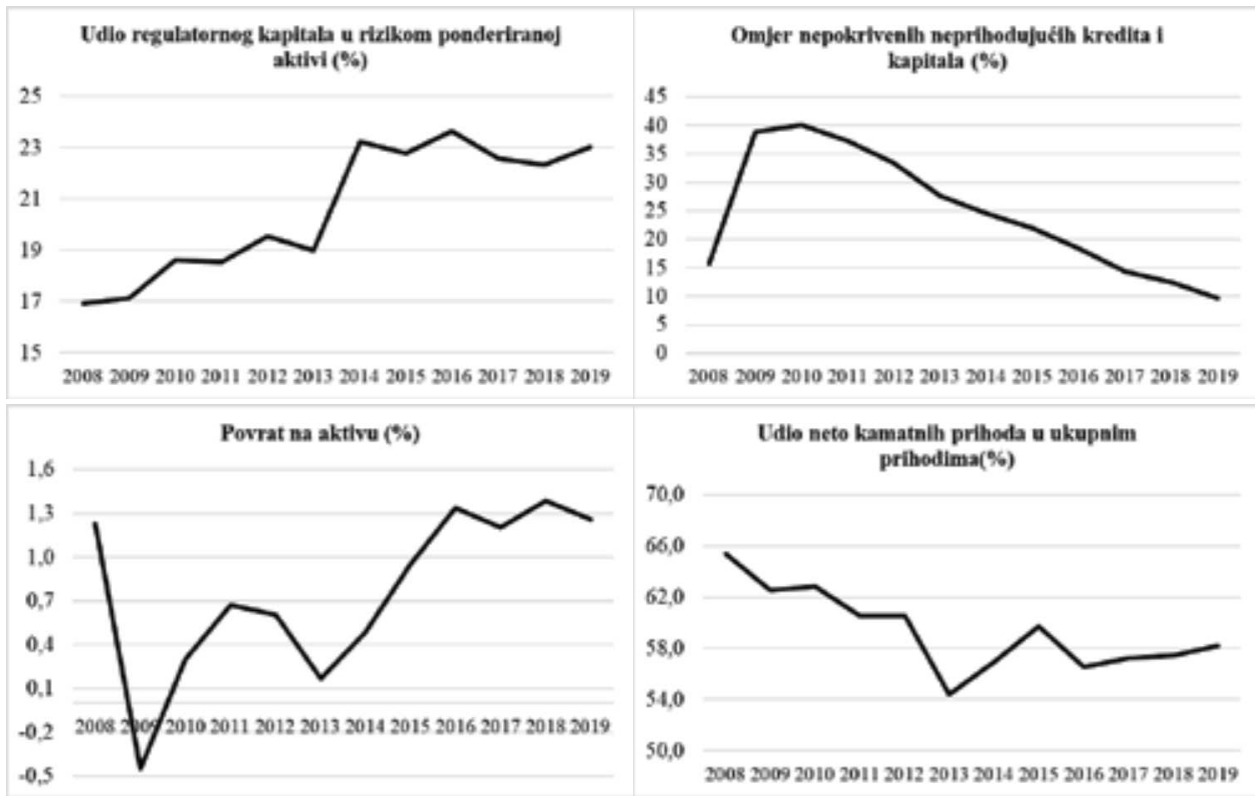

(*) Udio regulatornog kapitala u rizikom ponderiranoj aktivi: regulatorni kapital / rizikom ponderirana aktiva

(*) Omjer nepokrivenih neprihodujućih kredita i kapitala: neprihodujući krediti - pričuve za gubitke po neprihodujućim kreditima / kapital

(*) Povrat na aktivu: neto dobit / prosječna vrijednost aktive

(*) Udio neto kamatnih prihoda u ukupnim prihodima: neto kamatni prihod / ukupni prihod

Izvor: obrada autora prema Međunarodni monetarni fond (2021). Financial Soudness Indicators (FSIs). Dostupno na: https://data.imf.org/?sk=51B096FA-2CD2-40C2-8D09-0699CC1764DA [14. ožujka 2021.] 
Analiza kretanja razine neprihodujućih kredita (grafikon 2) ukazuje na snažan porast neprihodujućih kredita, uzrokovan svjetskom financijskom krizom, s relativno niskih $3,2 \%$ u 2008. godini do najviših $11,1 \%$ u 2012. Postotak neprihodujućih kredita pada od 2012. godine te je razlika između najviše i najniže razine takvih kredita među promatranim zemljama najviša u kriznim godinama, odnosno između 2008. i 2013. Prosječna kvaliteta bankovnih kredita u 2019. godini i dalje je niža nego prije krize na što ukazuje viša razina neprihodujućih kredita od one pretkrizne,a varijabilnost razine neprihodujućih kredita među zemljama tijekom i nakon financijske krize veća je nego u 2008. godini. Financijska kriza uzrokovala je porast vrijednosti razine neprihodujućih kredita iznad $20 \%$ u Litvi (2009. i 2010.) i Rumunjskoj (2013.), no vrijednosti su se značajno smanjile od tog vrhunca te su u 2019. u navedene dvije zemlje iznosile ispod $1,0 \%$ i 4,1\%. Tri zemlje s najvećom prosječnom vrijednosti udjela neprihodujućih kredita u cijelom razdoblju su Hrvatska (11,6\%), Bugarska $(10,8 \%)$ i Rumunjska (10,2 \%), a zemlje s najnižim udjelom su Češka $(4,5 \%)$, Poljska (4,3 \%) i Estonija (2,1 \%). U Hrvatskoj i Bugarskoj relativno visok udio neprihodujućih kredita (7,0 \% i 6,6 \%) evidentiran je čak i u 2019. godini, odnosno 10 godina nakon početka krize, što ukazuje na slabiju kvalitetu kredita u promatrane dvije zemlje. Sve ostale zemlje krajem 2019. ostvarile su udjele loših kredita od $5 \%$ ili niže.

Grafikon 2. Kretanje razine neprihodujućih kredita na razini zemalja

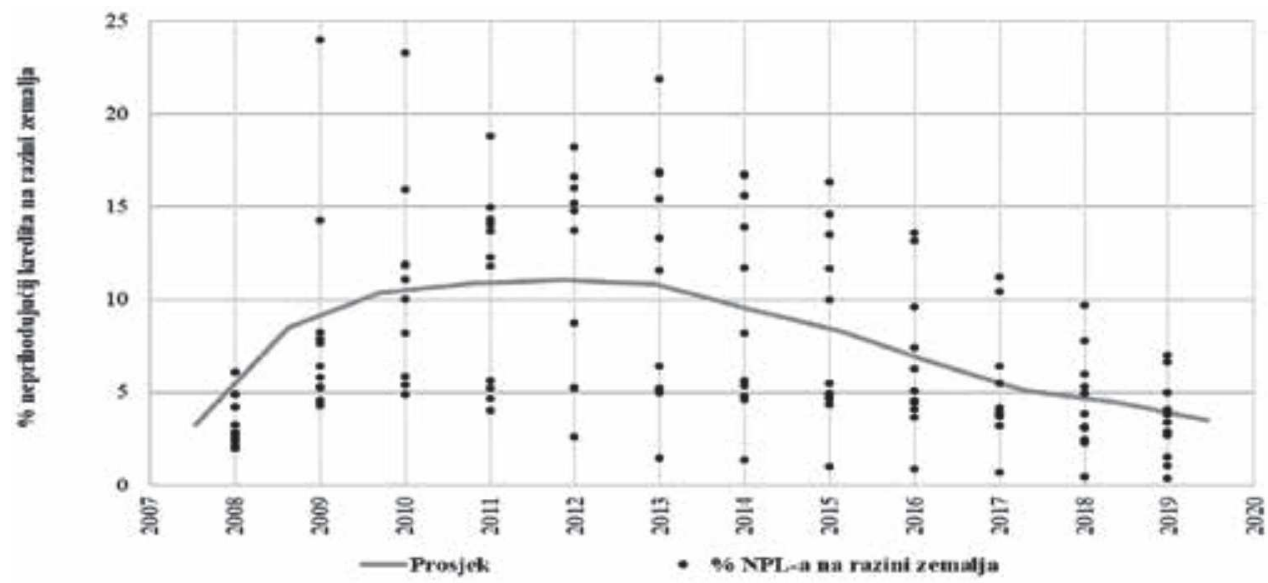

Izvor: obrada autora prema Međunarodni monetarni fond (2021). Financial Soudness Indicators (FSIs). Dostupno na: https://data.imf.org/?sk=51B096FA-2CD2-40C2-8D09-0699CC1764DA [14. ožujka 2021.]

\section{REZULTATI}

Prije same analize funkcije impulsnog odziva i dekompozicije varijance potrebno je utvrditi razinu stacionarnosti korištenih varijabli u modelu, učinkovit (optimalan) broj korištenih vremenskih odmaka (lagova) te provjeriti stabilnost korištenog panel VAR modela. Provedeni testovi stacionarnosti (tablica 3) ukazuju kako su sve korištene varijable u modelu stacionarne u svojim početnim razinama $(\mathrm{I}(0))$ te su uključene u model bez transformacija. 
Korišteni testovi za procjenu učinkovitog broja vremenskih pomaka (tablica 4) sugeriraju korištenje 2 ili 3 vremenska pomaka, a s obzirom na to da većina testova sugerira 3 vremenska pomaka, u modelu su korištena prva 3 vremenska odmaka (laga) varijabli. Stabilnost (stacionarnost) svih VAR modela, pa tako i panel VAR modela, dodatno se provjerava i procjenom AR korijena karakterističnog polinoma. Budući da su svi moduli karakterističnog polinom AR modela manji od 1 (unutar kruga), VAR model je stabilan i može se dalje analizirati funkcija impulsnog odziva i dekompozicija varijance (slika 1).

Tablica 3. Testovi stacionarnosti varijabli modela

\begin{tabular}{|l|r|r|r|}
\hline Varijabla & $\begin{array}{c}\text { Levin, Lin \& } \\
\text { Chu test }\end{array}$ & ADF test & PP test \\
\hline NPL & $-4,8^{*}$ & $45,9 *$ & $60,8^{*}$ \\
\hline KRED & $-8,1^{*}$ & $43,8^{*}$ & $48,1^{*}$ \\
\hline NEZ & $-4,8^{*}$ & $46,4 *$ & $82,0^{*}$ \\
\hline BDP & $-23,5 *$ & $118,6 *$ & $133,6 *$ \\
\hline
\end{tabular}

* razina signifikantnosti od $1 \%$.

Izvor: izrada autora.
Tablica 4. Testovi za procjenu broja vremenskog odmaka.

\begin{tabular}{|c|c|c|c|c|c|}
\hline Lag & LR & FPE & AIC & SC & HQ \\
\hline 0 & - & $62.345,98$ & 22,39 & 22,51 & 22,44 \\
\hline 1 & 671,00 & 18,69 & 14,28 & 14,86 & 14,51 \\
\hline 2 & 90,07 & 8,26 & 13,46 & $14,50 *$ & $13,88^{*}$ \\
\hline 3 & $27,93^{*}$ & $8,21 *$ & $13,45^{*}$ & 14,95 & 14,05 \\
\hline 4 & 19,42 & 9,11 & 13,54 & 15,51 & 14,33 \\
\hline
\end{tabular}

* najučinkovitiji broj vremenskih odmaka prema kriteriju.

Izvor: izrada autora.

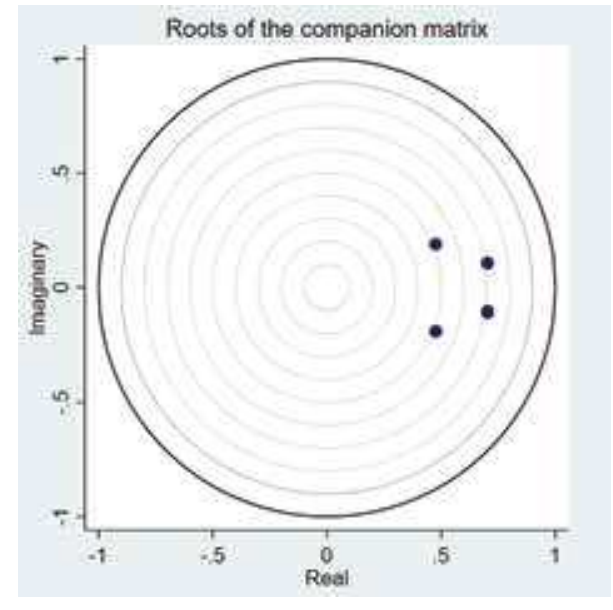

Slika 1. Test AR korijena karakterističnog polinoma

Izvor: izrada autora

Kumulativan utjecaj šoka od jedne standardne devijacije $(5,3 \%)$ razine neprihodujućih kredita na ostale varijable modela u razdoblju od 10 godina dobiven je korištenjem funkcije impulsnog odziva (slika 2). Šok razine neprihodujućih kredita uzrokuje trenutačni pad bruto domaćeg proizvoda od $0,53 \%$ te se negativan utjecaj povećava do 4 . godine kada iznosi $1,31 \%$, a nakon čega se utjecaj smiruje te blago smanjuje do kraja 10. godine. Udio kredita u bruto domaćem proizvodu reagira blago pozitivno, odnosno povećava se $0,49 \% \mathrm{u}$ 
1. godini, nakon čega se taj kumulativan utjecaj smanjuje te ima tendenciju kretanja prema 0 do kraja promatranog razdoblja. Treba istaknuti da je ovo jedina varijabla na koju šok razine neprihodujućih kredita nema značajan učinak budući da intervali pouzdanosti od $95 \%$ u cijelom razdoblju uključuju vrijednost 0 . Razina nezaposlenosti se $u 4$ godine povećava kao posljedica šoka neprihodujućih kredita za 2,36 \% te ostaje povećana do kraja promatranog razdoblja. Sličan utjecaj razina neprihodujućih kredita ima na samu razinu neprihodujućih kredita, tako da šok od jedne standardne devijacije povećava razinu neprihodujućih kredita za $4,73 \%$ u 4 godine.

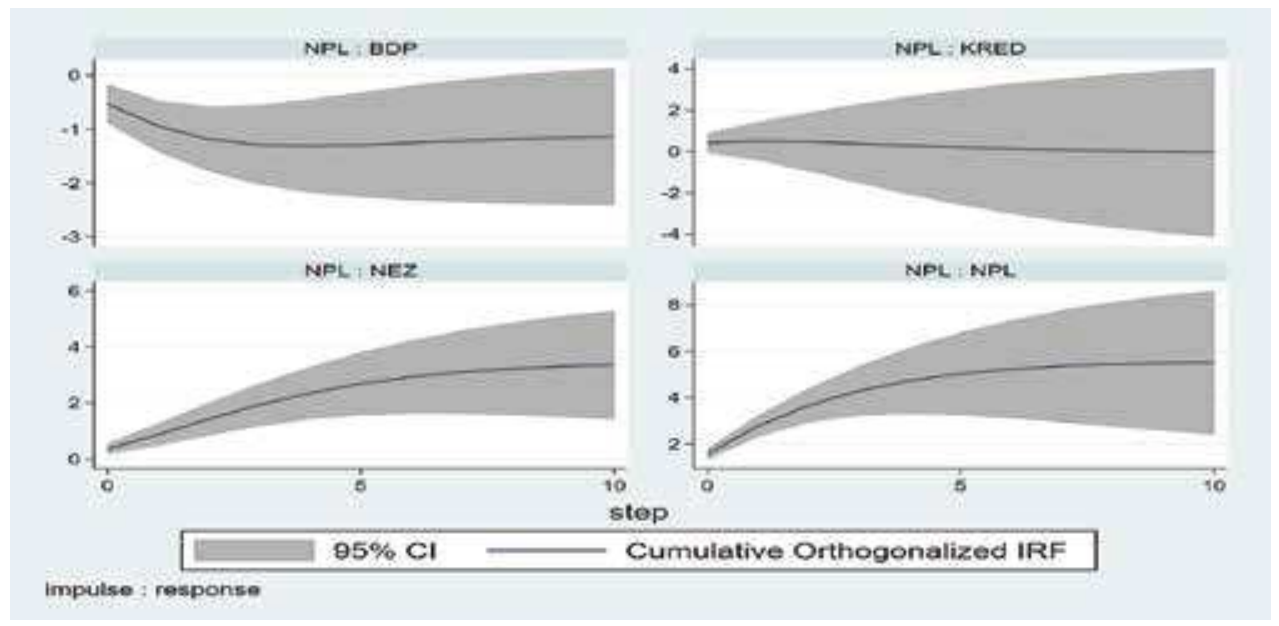

Slika 2. Funkcija impulsnog odziva (kumulativan utjecaj „šoka“ razine neprihodujućih kredita)

Izvor: izrada autora.

Dekompozicija varijance ukazuje kako šok varijable neprihodujućih kredita objašnjava značajan dio varijabilnosti većine varijabli modela, čime se dodatno potvrđuje značaj utjecaja na ekonomska kretanja (tablica 5). Osim što povećanje razine neprihodujućih kredita ima najveći utjecaj na varijabilnost same razine neprihodujućih kredita (84\% u 4 godine), objašnjava i značajan dio varijabilnosti razine nezaposlenosti (30 \%) te promjene razine bruto domaćeg proizvoda (16\%). Utjecaj na udio kredita u bruto domaćem proizvodu je relativno nizak ( $2 \%$ u većini promatranog razdoblja), čime se i dodatno potvrđuju rezultati funkcije impulsnog odziva o statistički neznačajnom utjecaju varijable razine neprihodujućih kredita na promatranu varijablu.

Rezultati dobiveni funkcijom impulsnog odziva (slika 2) i dekompozicijom varijabli (tablica 5) ukazuju kako povećanje razine neprihodujućih kredita ima najsnažniji i najdugotrajniji utjecaj na povećanje razine nezaposlenosti. Povećanje postotka takvih kredita utječe i na smanjenje razine BDP-a, ali je pad razine bruto domaćeg proizvoda najsnažniji u prve četiri godine. Šok varijable neprihodujućih kredita nema značajnijeg utjecaja na udio odobrenih kredita u bruto domaćem proizvodu. 
Tablica 5. Dekompozicija varijabli (utjecaj „šoka“ varijable neprihodujućih kredita)

\begin{tabular}{|c|c|c|c|c|}
\hline Broj godina & NPL & KRED & NEZ & BDP \\
\hline 1 & $100 \% *$ & $3 \%$ & $15 \%$ & $10 \%$ \\
\hline 2 & $97 \%$ & $2 \%$ & $20 \%$ & $15 \%$ \\
\hline 3 & $92 \%$ & $2 \%$ & $26 \%$ & $16 \%$ \\
\hline 4 & $87 \%$ & $2 \%$ & $30 \%$ & $16 \%$ \\
\hline 5 & $83 \%$ & $2 \%$ & $32 \%$ & $15 \%$ \\
\hline 6 & $80 \%$ & $2 \%$ & $34 \%$ & $15 \%$ \\
\hline 7 & $78 \%$ & $2 \%$ & $34 \%$ & $15 \%$ \\
\hline 8 & $77 \%$ & $2 \%$ & $34 \%$ & $15 \%$ \\
\hline 9 & $76 \%$ & $2 \%$ & $34 \%$ & $16 \%$ \\
\hline 10 & $76 \%$ & $2 \%$ & $34 \%$ & $16 \%$ \\
\hline
\end{tabular}

* Varijabla NPL je prva poredana u modelu te zbog toga u prvoj godini šok same varijable objašnjava $100 \%$ varijabilnosti iste varijable.

Izvor: izrada autora.

\section{RASPRAVA I ZAKLJUČAK}

Rezultati funkcije impulsnog odziva i dekompozicije varijance u promatranim zemljama dokazuju značajan i dugotrajan negativan učinak razine neprihodujućih kredita na stopu nezaposlenosti i rasta bruto domaćeg proizvoda. Udio kredita u bruto domaćem proizvodu jedina je promatrana varijabla na koju povećanje neprihodujućih kredita nema značajan učinak. Navedeno se može objasnite time što, zbog nedostupnosti podataka, nije bilo moguće izabrati varijablu razine odobrenih kredita, već je odabrana varijabla udjela kredita u bruto domaćem proizvodu. Samim time, vrijednost varijable ovisi o kretanju razine kreditne aktivnosti banaka, ali i bruto domaćeg proizvoda. Kako je u većini promatranih zemalja bio prisutan snažan pad razine bruto domaćeg proizvoda koji je često bio i veći od pada kreditne aktivnosti banaka, pokazatelj udjela kredita u bruto domaćem proizvodu se u razdoblju posljednje financijske krize čak i povećao u većini promatranih zemalja.

Važno je istaknuti da su krediti najvažniji eksterni izvor financiranja građanstva i poduzeća u promatranim zemljama, ali i u cijeloj Europskoj uniji. U usporedbi s primjerice Sjedinjenim Američkim Državama i Japanom, Europska je unija bila izrazito snažno pogođena financijskom i europskom dužničkom krizom. Zbog nedovoljne kvalitete aktive banaka u 2017. godini donesen je Akcijski plan za borbu protiv loših kredita s ciljem kvalitetnije supervizije u suradnji s bankama, poboljšanja sekundarnog tržišta loših kredita i restrukturiranja bankovnih sektora (Vijeće Europske unije, 2017; Europsko nadzorno tijelo za bankarstvo, 2018). Kao posljedica donesenog akcijskog plana te povoljnih ekonomskih kretanja smanjena je razina neprihodujućih kredita i rizika bankovnih sektora zemalja članica, a elementi akcijskog plana su ostvareni ili su u postupku provedbe (Europska komisija, 2019).

Zemlje Srednje, Istočne i Jugoistočne Europe (CESEE) poduzele su i dodatne mjere s ciljem poboljšanja kvalitete kreditnog portfelja banaka. U sklopu Bečke inicijative (engl. 
Vienna Iniative), osnovane 2009. s ciljem osiguranja i jačanja financijske stabilnosti u CESEE zemljama, 2012. godine pokrenuta je posebna „grupa za loše kredite“. Glavni cilj osnovane grupe bio je brže rješavanje (otpisivanje) neprihodujućih kredita putem sveobuhvatnog pristupa koji uključuje privatni, ali i javni sektor. Najvažnijim predloženim mjerama unutar inicijative mogu se istaknuti čvršća supervizija (realna procjena vrijednosti kolaterala i klasifikacije imovine), poboljšanje poreznog okvira za neprihodujuće kredite (usklađivanje poreza na dohodak i dobit prilikom restrukturiranja i prodaje imovine s postojećim tretmanom u regulatorne i financijske svrhe), jačanje prisilne naplate dugova te kvalitetnije upravljanje i prodaja neprihodujućih kredita (Bečka inicijativa, 2012). Posljednje dostupno izvješće Bečke inicijative ističe kako se razina neprihodujućih kredita znatno snizila od 2015. godine te je krajem 2020. iznosila 3,6 \%, neznatno iznad razine u EU-u (2,9 \%) (Bečka inicijativa, 2021).

Opisani negativan utjecaj posljednje financijske krize na ekonomska kretanja i kvalitetu bankovne aktive u CESEE zemljama i Europskoj uniji bitno je uzeti u razmatranje s obzirom na trenutnu neizvjesnost i krizu uzrokovanu pandemijom bolesti COVID-19. Unatoč dosad poduzetim ekonomskim i regulatornim mjerama, uključujući i moratorij na bankovne kredite, banke u budućnosti očekuju postrožavanje kreditnih standarda i procedura, manju kvalitetu bankovne aktive i veću razinu neprihodujućih kredita (Deloitte, 2020). Ohrabrujući pokazatelj u CESEE zemljama je bolja pripremljenost banaka na novu krizu kroz veću razinu kapitala i postojeće mjere za restrukturiranje kredita, a što može doprinijeti manjem i kraćem negativnom utjecaju pogoršanja kvalitete bankovne aktive na ekonomska kretanja (Bečka inicijativa, 2021).

Prilikom interpretacije rezultata modela u obzir treba uzeti činjenicu da je promatran veći broj zemalja i duže vremensko razdoblje. Samim time, moguće su promjene u definiciji neprihodujućih kredita unutar pojedine zemlje, a i razlike u definiciji neprihodujućih kredita među zemljama mogu uzrokovati blažu ili strožu klasifikaciju kredita u neprihodujuće kredite. Navedeno bi imalo utjecaja na same rezultate modela kroz slabiji ili snažniji utjecaj razine neprihodujućih kredita na promatrane ekonomske varijable. Buduća istraživanja iz ovog područja mogla bi se orijentirati na utjecaj povećanja razine neprihodujućih kredita unutar pojedinačnih banaka na poslovne rezultate banke, kao i na uključivanje dodatnih varijabli na kojima bi se razmatrao utjecaj povećanja neprihodujućih kredita (primjerice kretanje tečaja ili profitabilnosti bankovnog sustava).

\section{LITERATURA}

1. Abrigo, M. R. M. \& Love, I. (2016). Estimation of panel vector autoregression in Stata. The Stata Journal, 16 (3), 778-804. https://doi.org/10.1177/1536867X1601600314

2. Ari, A., Chen, S. \& Ratnovski, L. (2019). The Dynamics of Non-Performing Loans During Banking Crises: A New Database. Washington: Međunarodni monetarni fond. https://www.imf.org/en/Publications/WP/Issues/2019/12/06/The-Dynamics-of-Non-Performing-Loans-during-Banking-Crises-A-New-Database-48839

3. Association of Consumer Credit Information Suppliers (2021). ACCIS Membership Survey 2020: Analysis of Credit Reporting in Europe. Bruxelles: Association of Consumer Credit Information Suppliers. https://accis.eu/facts-and-figures/ 
4. Bahovec, V. \& Erjavec, N. (2009). Uvod u ekonometrijsku analizu. Zagreb: Element d.o.o.

5. Banka za međunarodna poravnanja (2018). Structural changes in banking after the crisis. Basel: Banka za međunarodna poravnanja. https://www.bis.org/publ/cgfs60. pdf

6. Baselski odbor za nadzor banaka (2016). Guidelines: Prudential treatment of problem assets - definitions of non-performing exposures and forbearance. Basel: Baselski odbor za nadzor banaka. https://www.bis.org/bcbs/publ/d403.pdf

7. Bečka inicijativa (2021). NPL Monitor for the CESEE Region: H2 2020. Beč: Bečka inicijativa. http://vienna-initiative.com/assets/Uploads/2020/334602ac2d/NPL-Monitor-2020-H2.pdf

8. Bečka inicijativa (2012). Working Group on NPLs in Central, Eastern and Southeastern Europe. Beč: Bečka inicijativa.https://ec.europa.eu/economy_finance/articles/ governance/pdf/2012-03-28-ebci-npls_en.pdf

9. Bernanke, B. \& Gertler, M. (1989). Agency Costs, Net Worth, and Business Fluctuations. The American Economic Review, 79(1), 14-31. https://www.jstor.org/stable/1804770

10. Bernanke, B., Gertler, M. \& Gilchrist, S. (1996). The Financial Accelerator and the Flight to Quality. The review of economics and statistics, 78 (1), 1-15. https://doi. org/10.2307/2109844

11. Bonin, J. P., Hasan, I. \& Wachtel, P. (2005). Privatization matters: Bank efficiency in transition countries. Journal of Banking \& Finance, 29 (8-9), 2155-2178. https://doi. org/10.1016/j.jbankfin.2005.03.012

12. Brooks, C. (2014). Introductory Econometrics for Finance, 3. izdanje. Cambridge: Cambridge University Press.

13. Canova, F. \& Ciccarelli, M. (2013). Panel Vector Autoregressive Models: A Survey. Frankfurt: Europska središnja banka. https://www.ecb.europa.eu/pub/pdf/scpwps/ ecbwp1507.pdf

14. Cappiello, L., Kadareja, A., Sørensen, C. K. \& Protopapa, M. (2010). Do Bank Loans and Credit Standards Have an Effect on Output: A Panel Approach for the Euro Area. Frankfurt: Europska središnja banka. https://www.ecb.europa.eu/pub/pdf/ scpwps/ecbwp1150.pdf

15. De Bock, M. R. \& Demyanets, M. A. (2012). Bank Asset Quality in Emerging Markets: Determinants and Spillovers. Washington: Međunarodni monetarni fond. https://www.imf.org/external/pubs/ft/wp/2012/wp1271.pdf

16. Deloitte (2020). COVID-19 CEE banking sector impact survey: First symptoms of the coronavirus outbreak. Budimpešta: Deloitte. https://www2.deloitte.com/lt/en/pages/ financelarticles/covid-19-cee-banking-sector-impact-survey.html

17. Demirgüc-Kunt, A. \& Levine, R. (1999). Bank-Based and Market-Based Financial Systems: Cross-Country Comparisons. Washington: Međunarodni monetarni fond. https://ideas.repec.org/p/wbk/wbrwps/2143.html

18. Espinoza, R. \& Prasad, A. (2010). Nonperforming Loans in the GCC Banking System and their Macroeconomic Effects. Washington: Međunarodni monetarni fond. https:// www.imf.org/external/pubs/ft/wp/2010/wp10224.pdf 
19. Europska bankovna federacija (2020). Banking in Europe: EBF Facts \& Figures 2020. Bruxelles: Europska bankovna federacija. https://www.ebf.eu/wp-content/uploads/2020/11/EBF_043537-Banking-in-Europe-EBF-Facts-and-Figures-2020.pdf

20. Europska komisija (2019). Četvrto izvješće o napretku u smanjenju loših kredita $i$ daljnjem smanjenju rizika u bankarskoj uniji. Bruxelles: Europska komisija. https:// eur-lex.europa.eu/legal-content/HR/TXT/?uri=CELEX:52019DC0278

21. Europska središnja banka (2020). Financial Integration and Structure in the Euro Area. Frankfurt: Europska središnja banka. https://www.ecb.europa.eu/pub/fie/html/ ecb.fie202003 197074785e.en.html

22. Europsko nadzorno tijelo za bankarstvo (2018). Final Report: Guidelines on management of non-performing and forborne exposures. London: Europsko nadzorno tijelo za bankarstvo.https://www.eba.europa.eu/sites/default/documents/files/documents/10180/2425705/371ff4ba-d7db-4fa9-a3c7-231cb9c2a26a/Final\%20Guidelines\%20 on\%20management\%20of\%20non-performing\%20and\%20forborne\%20exposures.pdf

23. Haselmann, R., Wachtel, P. \& Sobott, J. (2016). Credit Institutions, Ownership and Bank Lending in Transition Economies. U: Beck, T. \& Casu, B., ur., The Palgrave Handbook of European Banking. London: Palgrave Macmillan, 623-644.

24. Iwanicz-Drozdowska, M., Bongini, P., Smaga, P. \& Witkowski, B. (2018). Foreign-Owned Bank: The Role of Ownership in Post-Communist Countries. London: Palgrave Macmillan.

25. Kjosevski, J. \& Petkovski, M. (2017). Non-performing loans in Baltic States: determinants and macroeconomic effects. Baltic Journal of Economics, 17(1), 25-44. https:// doi.org/10.1080/1406099X.2016.1246234

26. Klein, N. (2013). Non-Performing Loans in CESEE: Determinants and Impact on Macroeconomic Performance. Washington: Međunarodni monetarni fond. https:// www.imf.org/en/Publications/WP/Issues/2016/12/31/Non-Performing-Loans-in-CESEE-Determinants-and-Impact-on-Macroeconomic-Performance-40413

27. Levine, R. (1997). Financial development and economic growth: views and agenda. Journal of economic literature, 35(2), 688-726.https://www.jstor.org/stable/2729790

28. Love, I. \& Zicchino, L. (2006). Financial development and dynamic investment behavior: Evidence from panel VAR. The Quarterly Review of Economics and Finance, 46(2), str. 190-210. https://doi.org/10.1016/j.qref.2005.11.007

29. Lucas Jr. R. E. (1988). On the mechanics of economic development. Journal of monetary economics, 22(1), 3-42. https://doi.org/10.1016/0304-3932(88)90168-7

30. Međunarodni monetarni fond (2019). Financial Soudness Indicators Compilation Guide. Washington: Međunarodni monetarni fond. https://data.imf.org/?sk=51B096FA2CD2-40C2-8D09-0699CC1764DA

31. Međunarodni monetarni fond (2012). Global Financial Stability Report, October 2012. Washington: Međunarodni monetarni fond. https://www.imf.org/en/Publications/GFSR/Issues/2016/12/31/Restoring-Confidence-and-Progressing-on-Reforms

32. Monokroussos, P. \& Gortsos, C. (2017). Non-Performing Loans and Resolving Private Sector Insolvency: Experiences from the EU Periphery and the Case of Greece. London: Palgrave Macmillan. 
33. Nkusu, M. (2011). Nonperforming Loans and Macrofinancial Vulnerabilities in Advanced Economies. Washington: Međunarodni monetarni fond. https://www.imf. org/external/pubs/ft/wp/2011/wp11161.pdf

34. Petkovski, M., Kjosevski, J. \& Jovanovski, K. (2018). Empirical Panel Analysis of Non-Performing Loans in the Czech Republic: What are their Determinants and How Strong is Their Impact on the Real Economy? Finance a Uver, 68(5), 460-490. https:// ideas.repec.org/a/fau/fauart/v68y2018i5p460-490.html

35. Schnücker, A. (2016). Restrictions Search for Panel VARs. Berlin: German Institute for Economic Research. https://www.diw.de/documents/publikationen/73/ diw_01.c.545784.de/dp1612.pdf

36. Schumpeter, J. A. (1911). The theory of economic development. Cambridge, MA: Harvard University Press.

37. Singh, A. (1997). Financial liberalisation, stockmarkets and economic development. The Economic Journal, 107(442), 771-782. https://www.jstor.org/stable/2957801

38. Vijeće Europske unije (2017) Council conclusions on Action plan to tackle non-performing loans in Europe. Bruxelles: Vijeće Europske unije. https://www.consilium. europa.eu/en/press/press-releases/2017/07/11/conclusions-non-performing-loans/

39. Vijeće Europske unije (2017.) Report of the FSC Subgroup on Non-Performing Loans. Bruxelles: Vijeće Europske unije. https://data.consilium.europa.eu/doc/document/ST9854-2017-INIT/en/pdf 